\title{
Follicular Lymphoma
}

\section{Foliküler Lenfoma}

\author{
İrfan Yavaşoğlu \\ Adnan Menderes University Faculty of Medicine, Department of Hematology, Aydin, Turkey
}

\section{To the Editor,}

The article entitled "Renal Infiltration of Follicular Lymphoma", written by Petkovic et al. and published in one of the recent issues of your journal, was quite interesting [1]. Here we would like to emphasize some relevant points.

Extranodal disease is relatively common; any organ may be involved. The most common sites of extranodal disease include the bone marrow, skin, gastrointestinal tract, and bone [2]. Diagnosis of primary renal lymphoma based on the axillary involvement may not be accurate.

There are two Follicular Lymphoma International Prognostic Index (FLIPI) scores: FLIPI scores 1 and 2. FLIPI 1 consists of age, Ann Arbor stage, hemoglobin level, serum LDH level, and number of nodal sites. FLIPI 2 consists of $\beta 2$ microglobulin, bone marrow involvement, hemoglobin level, largest diameter of lymph node, and age $[3,4]$. Treatment may be delayed if the following conditions are not present: B symptoms or pruritus, rapid generalized disease progression, marrow involvement, life-threatening organ involvement, renal infiltration, or bone lesions [5].

The results of the Primary Rituximab and Maintenance (PRIMA) study demonstrated an advantage in progressionfree survival for rituximab maintenance therapy offered after initial chemoimmunotherapy [2]. The patient should receive maintenance rituximab treatment.

\section{Conflict of Interest Statement}

The author of this paper have no conflicts of interest, including specific financial interests, relationships, and/ or affiliations relevant to the subject matter or materials included.

Key Words: Follicular lymphoma, FLIPI, Rituximab

Anahtar Sözcükler: Foliküler lenfoma, FLIPI, Rituksimab

Address for Correspondence: İrfan YAVAŞOĞLU, M.D.,

Adnan Menderes University Faculty of Medicine, Department of Hematology, Aydın, Turkey E-mail: dryavas@hotmail.com

Received/Geliş tarihi : September 24, 2014

Accepted/Kabul tarihi : September 25, 2014

94

\section{References}

1. Petkovic I, Krstic M, Pejcic I, Vrbic S, Stojnev S, Cvetanovic A, Balic M, Todorovic M. Renal infiltration of follicular lymphoma. Turk J Hematol 2014;3:315-316.

2. Gribben J. Clinical manifestations, staging, and treatment of follicular lymphoma. In: Hoffman R, Benz EJ Jr, Silberstein LE, Heslop H, Weitz J, Anastasi J. Hematology: Basic Principles and Practice. 6th ed. Philadelphia, PA, USA, Elsevier Saunders, 2013

3. Solal-Céligny $\mathrm{P}$, Roy $\mathrm{P}$, Colombat P, White J, Armitage JO, Arranz-Saez R, Au WY, Bellei M, Brice P, Caballero D, Coiffier B, Conde-Garcia E, Doyen C, Federico M, Fisher RI, Garcia-Conde JF, Guglielmi C, Hagenbeek A, Haïoun C, LeBlanc M, Lister AT, Lopez-Guillermo A, McLaughlin P, Milpied N, Morel P, Mounier N, Proctor SJ, Rohatiner A, Smith P, Soubeyran P, Tilly H, Vitolo U, Zinzani PL, Zucca E, Montserrat E. Follicular Lymphoma International Prognostic Index. Blood 2004;104:1258-1265.

4. Federico M, Bellei M, Marcheselli L, Luminari S, LopezGuillermo A, Vitolo U, Pro B, Pileri S, Pulsoni A, Soubeyran P, Cortelazzo S, Martinelli G, Martelli M, Rigacci L, Arcaini L, Di Raimondo F, Merli F, Sabattini E, McLaughlin P, SolalCéligny P. Follicular Lymphoma International Prognostic Index 2: A new prognostic index for follicular lymphoma developed by the international follicular lymphoma prognostic factor project. J Clin Oncol 2009;27:4555-4562.

5. Ardeshna KM, Smith P, Norton A, Hancock BW, Hoskin PJ, MacLennan KA, Marcus RE, Jelliffe A, Vaughan G, Hudson, Linch DC; British National Lymphoma Investigation. Longterm effect of a watch and wait policy versus immediate systemic treatment for asymptomatic advanced-stage nonHodgkin lymphoma: a randomised controlled trial. Lancet 2003;362:516-522. 


\section{Reply}

Thank you very much for your kind invitation to reply to comments on our article entitled "Renal Infiltration of Follicular Lymphoma" which has been published in your respected journal in volume 31 issue 3 in 2014.

We presented a rare case of follicular lymphoma (FL) which was diagnosed after nephrectomy of the involved kidney which is well documented in histopathology/immunochistochemistry pictures. The diagnosis was set up after CT scan which showed a renal mass mimicking renal cell carcinoma (RCC) but even so we avoided to use of the term primary renal lymphoma since we were not sure if it was FL which originated from the kidney or it was the infiltration of the kidney from the surrounding perirenal tissue. However, this is not relevant since it was extranodal FL for sure, which is quite rare to be found in the renal region of the body. After a surgery, performed CT scans of the body did not show the disease spreading so we decided to use a PET/CT scan, before making a decision on eventually "watch and wait" strategy. PET/CT scan found axillary lymph nodes to be positive with a high SUV ( $\max 7)$. The situation became debatable since the grade of FL was 3A and SUV was high and we assumed that FL might be transforming in a more aggressive variant such as diffuse large B-cell lymphoma (DLBCL). Both FLIPI indexes were counted for the patient but we mentioned only FLIPIl since there was a limited space for word counts for letters to the editor, so we did not have a place to comment on every aspect of analysis we have done. Our single institution decision was to treat the patient with R-CHOP. This can be debatable and we already commented in the text about our arguments to initiate induction therapy (grade 3 A and B can be treated like DLBCL as was appointed by one of the leading authorities in the field of FL treatment-Prof Ghielmini and there are publications that support the use of combined surgery+immunochemotherapy in renal lymphoma involvement but only if one kidney is involved [1], which was the situation with our patient). We already gave our arguments pro and contra the use of anthracyclines. The patient received 8 cycles and achieved a complete remission which was PET/CT verified.

If complete remission and long PFS is to be achieved, rituximab in combination with chemotherapy such as CHOP or bendamustine should be used [I, B] [2,3]. CVP combination results in inferior PFS, but no impact on OS was observed between these chemotherapy regimens [4].

Rituximab maintenance for 2 years improves PFS (75\% versus 58\% after 3 years, p<0.0001) [I, B] [5], whereas a shorter maintenance period results in inferior benefit $[5,6]$. Our patient underwent rituximab maintenance which still lasts; once again word counts were the major limiting factors to comment on every aspect of the treatment.

\section{Kind regards,}

Dr. Ivan Petkovic

\section{References}

1. Cupisti A, Riccioni R, Carulli G, Paoletti S, Tognetti A, Meola M, Francesca F, Barsotti G, Petrini M. Bilateral primary renal lymphoma treated by surgery and chemotherapy. Nephrol Dial Transplant 2004;19:1629-1633.

2. Rummel MJ, Niederle N, Maschmeyer G, Banat GA, von Grünhagen U, Losem C, Kofahl-Krause D, Heil G, Welslau M, Balser C, Kaiser U, Weidmann E, Dürk H, Ballo H, Stauch M, Roller F, Barth J, Hoelzer D, Hinke A, Brugger W; Study group indolent Lymphomas (StiL). Bendamustine plus rituximab versus $\mathrm{CHOP}$ plus rituximab as first-line treatment for patients with indolent and mantlecell lymphoma: an open-label, multicentre, randomised, phase 3 non-inferiority trial. Lancet 2013;381:1203-1210.

3. Flinn IW, van der Jagt R, Kahl BS, Wood P, Hawkins TE, Macdonald D, Hertzberg M, Kwan YL, Simpson D, Craig M, Kolibaba K, Issa S, Clementi R, Hallman DM, Munteanu M, Chen L, Burke JM. Randomized trial of bendamustine rituximab or R CHOP/R-CVP in first-line treatment of indolent NHL or MCL: the BRIGHT study. Blood 2014;123:2944-2952.

4. Federico M, Luminari S, Dondi A, Tucci A, Vitolo U, Rigacci L, Di Raimondo F, Carella AM, Pulsoni A, Merli F, Arcaini L, Angrilli F, Stelitano C, Gaidano G, Dell'olio M, Marcheselli L, Franco V, Galimberti S, Sacchi S, Brugiatelli M. R-CVP versus R-CHOP versus R-FM for the initial treatment of patients with advanced-stage follicular lymphoma: results of the FOLL05 trial conducted by the Fondazione Italiana Linfomi. J Clin Oncol 2013;31:1506-1513.

5. Salles GA, Seymour JF, Feugier P, Offner F, Lopez-Guillermo A, Belada D, Xerri L, Bouabdallah R, Catalano J, Pauline B, Caballero D, Haioun C, Pedersen LM, Delmer A, Simpson D, Leppa S, Soubeyran P, Hagenbeek A, Casanovas O, Intragumtornchai T, Ferme C, Gomes de Silva M, Sebban C, Lister A, Estell JA, Milone G, Sonet A, Coiffer B, Tilly H. Updated 6 year follow-up of the PRIMA study confirms the benefit of 2-year rituximab maintenance in follicular lymphoma patients responding to frontline immunochemotherapy. Blood 2013; 122: abstr. 509.

6. Taverna CJ, Martinelli G, Hitz F, Mingrone W, Pabst T, Cevreska L, del Giglio A, Vanazzi A, Laszlo D, Raats J, Rauch D, Vorobiof DA, Lohri A, Zucca E, Biaggi Rudolf C, Rondeau S, Rusterholz C, Ghielmini M. Rituximab maintenance treatment for a maximum of 5 years in follicular lymphoma: results of the randomized phase III trial SAKK 35/03. ASH 2013; 122; abstr. 508. 